\title{
Trichofolliculoma Mimicking Squamous Cell Carcinoma
}

\author{
Ahmed Abdelbary ${ }^{1}$, Hadir Shakshouk ${ }^{1}$ \\ 1 Department of Dermatology, Andrology and Venerology, Alexandria University, Egypt \\ Key words: trichofolliculoma, adnexal tumors, hamartoma, dermoscopy, case report \\ Citation: Abdelbary A, Shakshouk H. Trichofolliculoma mimicking squamous cell carcinoma. \\ Dermatol Pract Concept. 2022;12(1):e2022026. DOI: https://doi.org/10.5826/dpc.1201a26
}

Accepted: June 6, 2021; Published: January 2022

Copyright: $@ 2022$ Abdelbary and Shakshouk. This is an open-access article distributed under the terms of the Creative Commons Attribution-NonCommercial License (BY-NC-4.0), https://creativecommons.org/licenses/by-nc/4.0/, which permits unrestricted noncommercial use, distribution, and reproduction in any medium, provided the original authors and source are credited.

Funding: None.

Competing interests: None.

Authorship: Both authors have contributed significantly to this publication.

Corresponding author: Hadir Shakshouk, MBBS, MSc, Department of Dermatology, Andrology and Venerology, Alexandria University, Egypt. E-mail: drhadir58@gmail.com

\section{Introduction}

Trichofolliculoma, a rare follicular hamartoma, manifests itself as a solitary papule or nodule in adults involving the head and neck region. It is characterized by a single primary cystic structure from which radiates numerous secondary hair follicles. While dermoscopy has been widely used as a diagnostic tool, dermoscopic features of adnexal lesions are poorly described owing to their rarity and inadequate reporting.

\section{Case Presentation}

We describe a 75-year-old male patient who presented with asymptomatic solitary nodule on the forehead of 2-years duration. Upon examination, a single nodule of $1 \mathrm{~cm}$ diameter with central crust and raised border was noted on his forehead (Figure 1A). Dermoscopic evaluation revealed a nodule with central crusting, multiple fine linear vessels, and whitish circles mainly on the margin (Figure 1B).
These features were highly suggestive of squamous cell carcinoma. However, histopathological examination demonstrated multiple cystically dilated follicular infundibula lined by stratified squamous epithelium with numerous vellus hair follicles originating from them. Multiple lobules of follicles of varying maturity were observed radiating from these dilated follicular infundibula. Some showed sebaceous glands. A fibrocellular stroma surrounding the tumor was noted (Figure 1C). Thus, a diagnosis of trichofolliculoma was made.

Written informed consent for publication of clinical details and clinical images was obtained from the patient.

\section{Conclusions}

Trichofolliculoma is considered to be a rare follicular hamartoma that classically manifests as a papule or nodule with a central dilated pore and tufted hairs. This presentation corresponds histopathologically to a central primary follicle with many radiating secondary vellus hair follicles. 


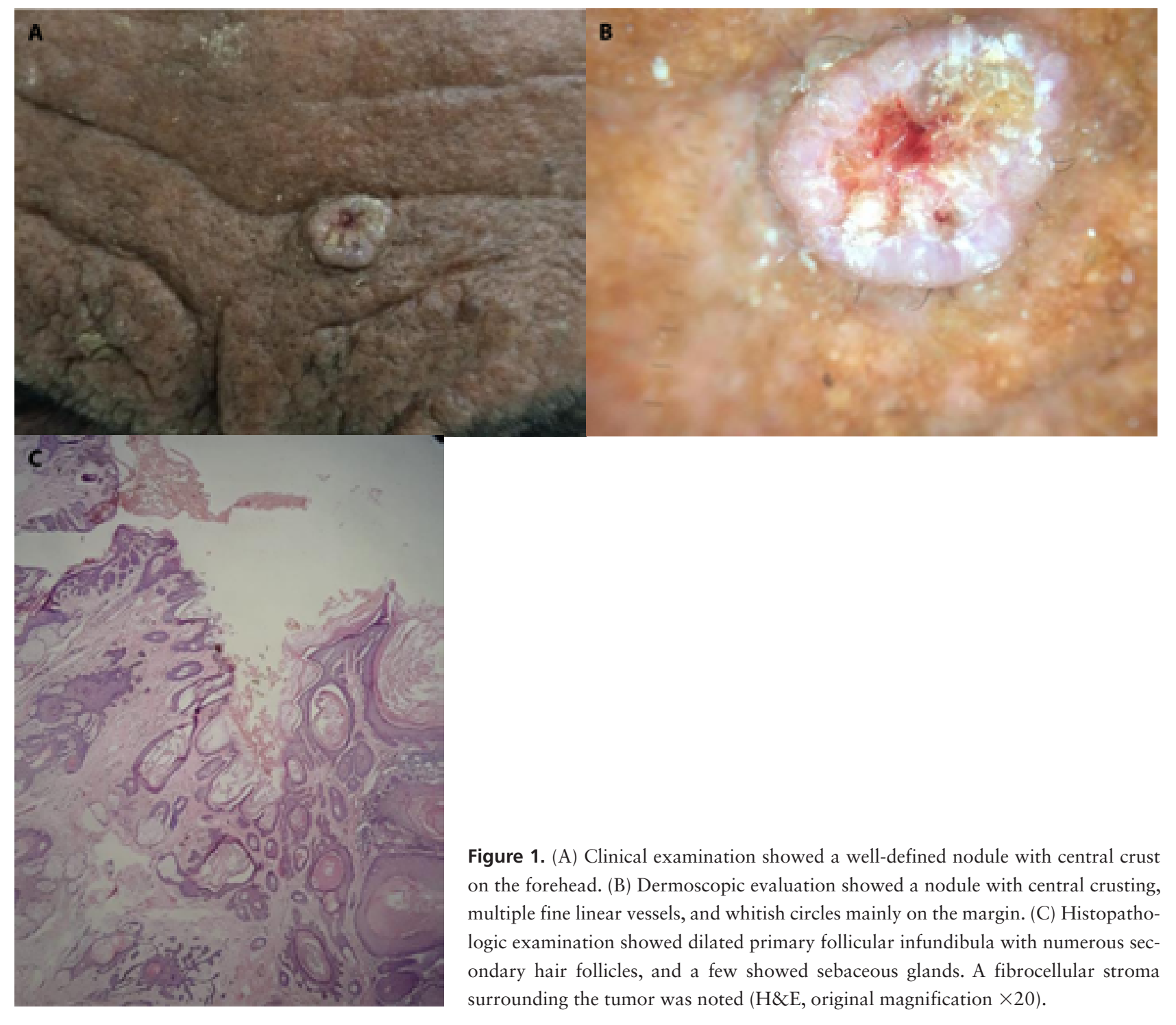

Figure 1. (A) Clinical examination showed a well-defined nodule with central crust on the forehead. (B) Dermoscopic evaluation showed a nodule with central crusting, multiple fine linear vessels, and whitish circles mainly on the margin. (C) Histopathologic examination showed dilated primary follicular infundibula with numerous secondary hair follicles, and a few showed sebaceous glands. A fibrocellular stroma

While thought to be diagnostic for trichofolliculoma, few cases demonstrate central hair tufting. The lack of a central hair plug, as in our case, renders the clinical diagnosis challenging.

Dermoscopy of trichofolliculoma is not well described in literature. Panasiti et al reported a patient with single nodule suspicious for basal cell carcinoma [1]. However, dermoscopic examination revealed a central brown zone with radial brown projections without pigment network, which was described by the authors as a "firework" pattern. These projections correlated histopathologically with the nests of cells radiating from a follicular epithelium [1]. Garcia-Garcia and colleagues described different dermoscopic features that included a well-defined bluish nodule with a whitepink central area, shiny white structures, dotted vessels, and a central scale in one patient [2]. Histopathologically, the early stages demonstrated few secondary vellus hair follicles originating from a primary follicle, whereas mature lesions showed increased number of vellus hair follicles. In later stages, thickened primary follicle with fewer secondary follicles could be seen [2].

Trichofolliculoma classically presents with a hair plug emanating from the center of a nodule; however, hair plug may be absent in many cases, making the diagnosis challenging. In these cases, other serious diagnoses should be ruled out. Dermoscopy of trichofolliculoma is poorly described in the literature. We introduce the possibility of new dermoscopic findings of trichofolliculoma.

\section{References}

1. Panasiti V, Roberti V, Lieto P, Visconti B, Calvieri S, Perrella E. The "firework" pattern in dermoscopy. Int J Dermatol.2013;52(9):11581159. DOI: 10.1111/j.1365-4632.2011.05122.x. PMID: 22591242.

2. Garcia-Garcia SC, Villarreal-Martinez A, Guerrero-Gonzalez GA, Miranda-Maldonado I, Ocampo-Candiani J. Dermoscopy of trichofolliculoma: a rare hair follicle hamartoma. J Eur Acad Dermatology Venereol. 2017;31(2):e123-e124. DOI: 10.1111/ jdv.13870. PMID: 27504964. 